\title{
Urinary Prostasin: A Possible Biomarker for Renal Pressure Natriuresis in Black Adolescents
}

\author{
HAIDONG ZHU, JULIE CHAO, DEHUANG GUO, KE LI, YING HUANG, KIMBERLY HAWKINS, NIKKI WRIGHT, \\ INGER STALLMANN-JORGENSEN, WEILI YAN, GREGORY A. HARSHFIELD, AND YANBIN DONG
}

Department of Pediatrics [H.Z., D.G., K.L., Y.H., K.H., N.W., I.S.-J., W.Y., G.A.H., Y.D.], Medical College of Georgia, Augusta, Georgia 30907; Department of Biochemistry and Molecular Biology [J.C.], Medical University of South Carolina, Charleston, South Carolina 29425

\begin{abstract}
Prostasin is a membrane-bound/secretive serine protease interacting with aldosterone and the epithelial sodium channel in the kidney. We and others have previously proposed the concept of stress-induced pressure natriuresis (SIPN) where increased urinary sodium excretion $\left(\mathrm{U}_{\mathrm{Na}} \mathrm{V}\right)$ is coupled with elevated blood pressure (BP) in response to behavioral stress in normotensive adolescents. This study thus aimed to test the relationship between prostasin and pressure natriuresis using the SIPN model. A cohort of 102 normotensive black adolescents (mean age: $17.0 \pm 1.2 \mathrm{y} ; 56 \%$ females) were placed on a controlled sodium $(4000 \pm 200 \mathrm{mg} / \mathrm{d})$ and potassium $(2600 \pm 200 \mathrm{mg} / \mathrm{d})$ diet for three days before testing. The SIPN protocol consisted of a 1-h baseline period, a 1-h stress period (competitive video game), and a $1-\mathrm{h}$ recovery period. During the stress period, BP elevation was coupled with an increase in $\mathrm{U}_{\mathrm{Na}} \mathrm{V}$. Urinary prostasin concentration had more than a 2-fold reduction from baseline $(38.4 \pm 32.7 \mathrm{ng} / \mathrm{mL})$ to stress $(17.2 \pm 16.0 \mathrm{ng} / \mathrm{mL})$, and further declined during recovery $(12.1 \pm 16.2 \mathrm{ng} / \mathrm{mL})(p<$ $0.001)$. Urinary prostasin was inversely correlated with $\mathrm{U}_{\mathrm{Na}} \mathrm{V}$ during stress $(r=-0.43, p=0.0001)$, even after being normalized by urinary creatinine. Our data suggest that urinary prostasin could be a novel biomarker and/or mechanism for renal pressure natriuresis in normotensive black adolescents. (Pediatr Res 65: 443-446, 2009)
\end{abstract}

$\mathrm{R}^{\mathrm{c}}$ enal pressure natriuresis, one of the key mechanisms of blood pressure (BP) homeostasis (1), is critically dependent upon the activity of sodium channels and transporters expressed in the nephron. Chief among these are the epithelial sodium channels $(\mathrm{ENaC})$ consisting of three subunits, $\alpha \mathrm{ENaC}$, $\beta \mathrm{ENaC}$, and $\gamma \mathrm{ENaC}$ in the cortical collecting duct $(2,3)$. Although sodium reabsorption by $\mathrm{ENaC}$ accounts for only a relatively small proportion (less than 5\%), it constitutes the rate-limiting step and the final renal adjustment to sodium balance (4).

Multiple mechanisms such as hormones, intracellular factors, and accessory regulatory proteins regulate $\mathrm{ENaC}$ function $(2,3)$. Aldosterone stimulates $\mathrm{ENaC}$ expression and activates an ENaC-regulating protein kinase, serum, and glucocorticoid-regulated kinase 1 (SGK1). SGK1 inhibits $\mathrm{ENaC}$ ubiquitination by an ubiquitin ligase, the neural precursor cell expressed developmentally down-regulated 4-like protein (Nedd4L), and subsequently prevents channel degrada-

Received June 30, 2008; accepted November 18, 2008.

Correspondence: Yanbin Dong, M.D., Ph.D., Georgia Prevention Institute, Department of Pediatrics, Medical College of Georgia, 1120 15th Street, HS-1640, Augusta, GA 30912-3715; e-mail: ydong@mcg.edu

Supported by grant HL077230 from National Heart, Lung, and Blood Institute. tion. A series of studies previously indicated that numerous proteases such as prostasin, a glycosylphosphatidylinositol (GPI)-anchored serine protease expressed in the distal nephron, are involved in the proteolytic processing and activation of $\mathrm{ENaC}$ subunits in Xenopus oocytes and a mouse cortical collecting duct cell line (5-16). Prostasin was thought to induce cleavage of an inhibitory peptide from $\gamma \mathrm{ENaC}$ to activate the channel fully in the cell (16-18). Of interest, aldosterone enhanced the expression of prostasin mRNA and protein in the cultured mouse cortical collecting duct cell line and in rats (19). In contrast, a single injection of adenovirus carrying the human prostasin gene caused a prolonged (3-4 wk) increase in BP and plasma aldosterone concentration in rats, indicating that prostasin may cause BP elevation via the stimulation of aldosterone (20). Furthermore, a decrease in urinary prostasin excretion by a synthetic prostasin inhibitor resulted in an increase in urinary sodium excretion in SpragueDawley rats (21). These findings suggest that prostasin may participate in tubular sodium reabsorption and pressure natriuresis via either direct effects on $\mathrm{ENaC}$ or interactions with aldosterone.

Comparable data in humans are scarce. Therefore, the purpose of this study was to examine the relationship among prostasin and renal pressure natriuresis in normotensive adolescents by using our stress-induced pressure natriuresis (SIPN) model (22-27). This model examines changes in pressure natriuresis induced by mental stress, which consists of a 1-h baseline period, a 1-h stress period (competitive video games), and a 1-h recovery period. The SIPN hypothesis postulates that a stress-induced increase in BP leads to a corresponding increase in urinary sodium excretion $\left(\mathrm{U}_{\mathrm{Na}} \mathrm{V}\right)$. Impaired stress-induced sodium regulation and resultant extracellular volume expansion may lead to the future development of hypertension and its sequelae. The second goal of this study was to examine the interaction between aldosterone and prostasin during SIPN. We examined healthy normotensive black adolescents because 1) healthy normotensive adolescents may not have yet developed significant target organ damage, which can mask or compromise the normal response pattern; 2) the pressure natriuresis concept is particularly appealing owing to the greater sensitivity of BP to sodium in

Abbreviations: BP, blood pressure; ENaC, epithelial sodium channel; SIPN, stress-induced pressure natriuresis; $\mathbf{U}_{\mathbf{N a}} \mathbf{V}$, urinary sodium excretion 
blacks compared with their white counterparts $(28,29)$; and 3) urinary prostasin could be used as a possible biomarker to screen adolescents at risk of BP elevation.

\section{METHODS}

Subject recruitment. The protocol was approved by the Human Assurance Committee of the Medical College of Georgia. A sample of 102 healthy normotensive black adolescents including 45 males and 57 females were recruited from local public high schools in the Augusta-Richmond County area via school announcements, flyers, handout, or word of mouth. Written informed parental consent and subject assent were obtained before testing. Black race (African American) was identified by self-report of each subject and by parent if the subject was less than $18 \mathrm{y}$. Normotension was based on BP screening, namely, $<95$ th percentile for age, sex and height, or $<140 / 90$ $\mathrm{mm} \mathrm{Hg}$ for subjects aged $18 \mathrm{y}$ or older (30). Other exclusion criteria included any chronic illness, medication use, or a positive pregnancy test.

Protocol. Weight, height, and BP were obtained at a screening visit before initiating the study protocol. The SIPN protocol has been previously described in detail (25-27). Briefly, subjects were placed on a controlled sodium and potassium diet for $3 \mathrm{~d}$ before testing. To do this, we met with the subjects before the week of their scheduled testing and planned each meal for each day, based on an average sodium and potassium intake of $4000 \pm 200 \mathrm{mg} / \mathrm{d}$ and $2600 \pm 200 \mathrm{mg} / \mathrm{d}$, respectively. Girls were not tested while on their menses, and were tested on the week after the completion of menstrual flow to ensure all girls were tested in the same phase of their menstrual cycle. During the test week the meals were packed into coolers each day and the subjects or parents picked up the coolers from the Georgia Prevention Institute. Overnight urine collection was used to estimate the subject's compliance with the sodium-controlled diet. On the fourth day the subjects performed the stress test, after having a breakfast provided. They were seated in a comfortable chair for the entire protocol, and ambulation was only allowed for collection of urine samples. The subjects emptied their bladders at the beginning of the baseline period. The protocol included a baseline period of $1 \mathrm{~h}$ (hour 1) during which the subjects watched a movie. This was followed by a 1-h stress period (hour 2) during which a competitive video game task (Snowboarding, Sony Corp., Foster City, CA) was played for a monetary reward between two subjects. Finally, there was a 1-h poststress recovery period (hour 3 ) that was the same as the baseline period. Urine samples were obtained hourly, and hour 1 was considered as baseline $\mathrm{U}_{\mathrm{Na}} \mathrm{V}$ to insure that the subjects had similar urinary flow rates. Hour 2 and hour 3 were considered stress $\mathrm{U}_{\mathrm{Na}} \mathrm{V}$ and recovery $\mathrm{U}_{\mathrm{Na}} \mathrm{V}$, respectively. BP was measured by a Dinamap monitor (Dinamap Compact Monitor, Tampa, FL) at an interval of $15 \mathrm{~min}$. The individual $\mathrm{BP}$ values during each hour were averaged to obtain baseline BP (hour 1), stress BP (hour 2), and recovery BP (hour 3). The subjects were required to drink $250 \mathrm{~mL}$ of water every hour to insure that they remained hydrated and provided adequate urine samples.

Human urinary prostasin measurement. Urinary levels of immunoreactive human prostasin were determined by enzyme-linked immunosorbent essay (ELISA) prepared with the previously described antibody to human prostasin (31). Microtiter plates (96-well) were coated with anti-prostasin IgG (IgG) $\left(1 \mu \mathrm{g} / \mathrm{mL}, 100 \mu \mathrm{L}\right.$ per well) overnight at $4^{\circ} \mathrm{C}$. Purified prostasin standards $(0.16-10 \mathrm{ng})$ or samples were added to individual wells in a total volume of $100 \mu \mathrm{L}$ of PBS containing $0.05 \%$ Tween 20 and $0.5 \%$ gelatin (dilution buffer) and incubated at $37^{\circ} \mathrm{C}$ for $90 \mathrm{~min}$. Biotin-labeled anti-human prostasin IgG was added in each well at a concentration of $1 \mu \mathrm{g} / \mathrm{mL}$ in a total of $100 \mu \mathrm{L}$ and incubated at $37^{\circ} \mathrm{C}$ for $60 \mathrm{~min}$. Peroxidase-avidin at a concentration of $1 \mu \mathrm{g} / \mathrm{mL}$ in a total volume of $100 \mu \mathrm{L}$ was added and incubated at $37^{\circ} \mathrm{C}$ for $30 \mathrm{~min}$. The color reaction was performed by adding $100 \mu \mathrm{L}$ of freshly prepared substrate solution [0.03\% 2,2'-azino-bis(3ethylbenzthiazoline-6-sulfonic acid) and $0.03 \% \mathrm{H}_{2} \mathrm{O}_{2}$ in $0.1 \mathrm{M}$ sodium citrate $(\mathrm{pH} 4.3)]$ to each well and incubating the mixture at room temperature for 30 min. The plates were read at $405 \mathrm{~nm}$ with a plate reader (Titertek Instruments, Huntsville, AL).

Aldosterone, electrolyte, and creatinine measurements. Aldosterone levels were determined using a competitive enzyme RIA kit (Diagnostic Systems Laboratories, Webster, TX). The sensitivity of the assay was $12 \mathrm{pg} / \mathrm{mL}$. Intra-assay coefficient of variation was $7.1 \%$; and inter-assay coefficient of variation was $13.2 \%$.

Electrolytes and creatinine were analyzed by the ion-selective electrode technique using a NOVA 16 Analyzer (NOVA Biomedical, Waltham, MA). The NOVA has an intra-assay coefficient of variation of less than $3 \%$ and an inter-assay coefficient of $4 \%$.

Statistical analyses. The general characteristics of subjects were presented as mean $\pm \mathrm{SD}$. The variations of clinical phenotypes among baseline (hour 1), stress (hour 2), and recovery (hour 3 ) were analyzed by repeated measures ANOVA, with adjustment of age, sex, and body mass index (BMI). The correlations between urinary prostasin concentration and urinary prostasin concentration normalized by urinary creatinine, and $\mathrm{U}_{\mathrm{Na}} \mathrm{V}$ or plasma aldosterone were tested by simple bivariate correlation analyses, or partial correlation analyses to adjust for potential confounders such as age, sex, and BMI. Log-transformation was performed to obtain approximation of normal distribution when necessary. A value of $p<0.05$ was deemed statistically significant. The statistical analyses were performed with STATA 8.0 (StataCorp, College Station, TX).

\section{RESULTS}

The subject characteristics are presented in Table 1. Subjects were normotensive black adolescents aged $17.0 \pm$ $1.2 \mathrm{y}$. The average height of the subjects was $170.2 \pm 8.7$ $\mathrm{cm}$, and the average BMI was $25.3 \pm 5.4 \mathrm{~kg} / \mathrm{m}^{2}$. The values of plasma creatinine and plasma aldosterone were within normal ranges. Urinary prostasin was detectable in every subject, regardless of sex.

As shown in Table 1, the increment of systolic BP (SBP) and diastolic BP (DBP) from baseline (hour 1) to stress (hour

Table 1. General clinical characteristics

\begin{tabular}{|c|c|c|c|c|c|c|}
\hline & Baseline & Stress & Recovery & $P_{\text {overall }}$ & $P_{\mathrm{b}-\mathrm{s}}$ & $P_{\mathrm{s}-\mathrm{r}}$ \\
\hline Age, y $(n=102)$ & $17.0 \pm 1.2$ & - & - & - & - & - \\
\hline Male/female & $45 / 57$ & - & - & - & - & - \\
\hline Height, cm & $170.2 \pm 8.7$ & - & - & - & - & - \\
\hline BMI, $\mathrm{kg} / \mathrm{m}^{2}$ & $25.3 \pm 5.4$ & - & - & - & - & - \\
\hline $\mathrm{SBP}, \mathrm{mm} \mathrm{Hg}$ & $110 \pm 12$ & $115 \pm 12$ & $109 \pm 11$ & $<0.001$ & $<0.001$ & $<0.001$ \\
\hline $\mathrm{DBP}, \mathrm{mm} \mathrm{Hg}$ & $60 \pm 6$ & $64 \pm 6$ & $60 \pm 6$ & $<0.001$ & $<0.001$ & $<0.001$ \\
\hline Plasma sodium, mmol/L* & $136.7 \pm 5.6$ & $135.8 \pm 6.0$ & $136.2 \pm 5.1$ & 0.441 & 0.205 & 0.631 \\
\hline Plasma potassium, $\mathrm{mmol} / \mathrm{L}^{*}$ & $4.4 \pm 0.3$ & $4.3 \pm 0.4$ & $4.3 \pm 0.3$ & 0.911 & 0.888 & 0.775 \\
\hline Plasma creatinine, $\mathrm{mg} / \mathrm{dL}^{*}$ & $1.0 \pm 0.4$ & $0.9 \pm 0.4$ & $0.9 \pm 0.4$ & 0.038 & 0.046 & 0.685 \\
\hline Plasma aldosterone, $\mathrm{pg} / \mathrm{mL}^{*}$ & $115.1 \pm 61.0$ & $99.9 \pm 57.1$ & $101.5 \pm 55.2$ & $<0.001$ & $<0.001$ & 0.521 \\
\hline Urinary creatinine, $\mathrm{mg} / \mathrm{dL}^{*}$ & $114.8 \pm 95.0$ & $65.0 \pm 49.4$ & $53.4 \pm 46.5$ & $<0.001$ & $<0.001$ & $<0.001$ \\
\hline Urinary prostasin concentration, $\mathrm{ng} / \mathrm{mL}$ & $38.4 \pm 32.7$ & $17.2 \pm 16.0$ & $12.1 \pm 16.2$ & $<0.001$ & $<0.001$ & $<0.001$ \\
\hline Urinary prostasin excretion, $\mathrm{ng} / \mathrm{mg} \dagger$ & $28 \pm 11$ & $26 \pm 11$ & $23 \pm 10$ & 0.005 & 0.038 & 0.014 \\
\hline $\mathrm{U}_{\mathrm{Na}} \mathrm{V}, \mathrm{mEq} / \mathrm{h} *$ & $7.0 \pm 4.1$ & $12.9 \pm 8.5$ & $9.9 \pm 6.8$ & $<0.001$ & $<0.001$ & 0.041 \\
\hline
\end{tabular}

* Analyses were performed based on log-transformed data.

$\dagger$ Urinary prostasin excretion was calculated as urinary prostasin concentration divided by urinary creatinine concentration.

Values $=$ means \pm SD. The repeated ANOVA analyses were applied to analyze the overall and subgroup differences in variables across baseline (hour 1), stress (hour 2), and recovery (hour 3), with adjustment of age, sex, and BMI. $P_{\mathrm{b}-\mathrm{s}}$, baseline to stress; $P_{\mathrm{s}-\mathrm{r}}$, stress to recovery. 


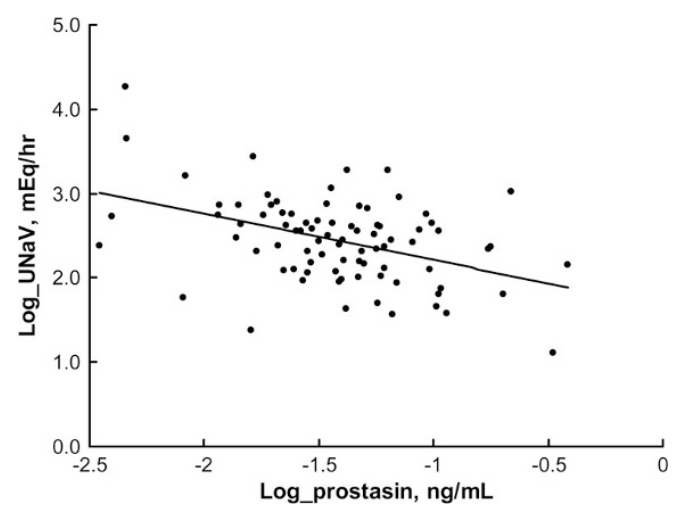

Figure 1. Correlations between urinary prostasin normalized by creatinine and $\mathrm{U}_{\mathrm{Na}} \mathrm{V}$ during stress. There were significant and negative correlations between urinary prostasin excretion (urinary prostasin concentration normalized by urinary creatinine concentration) and $\mathrm{U}_{\mathrm{Na}} \mathrm{V}$ during stress $(r=-0.43$, $p=0.0001$ ) (adjusted for age, sex, and body mass index).

2) was $\sim 4$ to $5 \mathrm{~mm} \mathrm{Hg}$, and both SBP and DBP dropped significantly during recovery (hour 3) compared with stress (Ps $<0.001$ ). Similarly, $\mathrm{U}_{\mathrm{Na}} \mathrm{V}$ was increased almost 2-fold from baseline $(7.0 \pm 4.1 \mathrm{mEq} / \mathrm{h})$ to stress $(12.9 \pm 8.5 \mathrm{mEq} / \mathrm{h})$ $(p<0.001)$, and declined during recovery $(9.9 \pm 6.8 \mathrm{mEq} / \mathrm{h})$ compared with stress $(p=0.04)$. Conversely, urinary prostasin concentration had more than a 2 -fold reduction from baseline $(38.4 \pm 32.7 \mathrm{ng} / \mathrm{mL})$ to stress $(17.2 \pm 16.0 \mathrm{ng} / \mathrm{mL})$, and continuously declined during recovery $(12.1 \pm 16.2 \mathrm{ng} /$ $\mathrm{mL})$ compared with stress $(p<0.001)$. As shown in Figure 1 , urinary prostasin was inversely correlated with $\mathrm{U}_{\mathrm{Na}} \mathrm{V}$ during stress $(r=-0.43, p=0.0001)$, even after being normalized by urinary creatinine. Urinary prostasin did not correlate with $\mathrm{U}_{\mathrm{Na}} \mathrm{V}$ at baseline $(r=0.06, p=0.60)$ or $\mathrm{U}_{\mathrm{Na}} \mathrm{V}$ during recovery $(r=0.07, p=0.3)$.

Plasma levels of aldosterone were significantly reduced during stress $(99.9 \pm 57.1 \mathrm{pg} / \mathrm{mL})$ compared with baseline $(115.1 \pm 61.0 \mathrm{pg} / \mathrm{mL})$ and remained lower during recovery $(101.5 \pm 55.2 \mathrm{pg} / \mathrm{mL})(p<0.001)$. We did not find any significant correlations between aldosterone, and $\mathrm{U}_{\mathrm{Na}} \mathrm{V}$ or prostasin at baseline, stress, or recovery.

\section{DISCUSSION}

For sodium balance to be maintained in the face of increased arterial pressure, there must be a shift of renal pressure natriuresis to higher $\mathrm{BP}(1,32)$. The laboratory-based pressure natriuresis model (SIPN) exhibited a higher rate of $\mathrm{U}_{\mathrm{Na}} \mathrm{V}$ when $\mathrm{BP}$ was elevated, which is a normal natriuretic response in healthy normotensive adolescents. We undertook this study to test for the relationship between urinary prostasin and the natriuretic process in response to stress-induced BP elevation, after controlling dietary sodium and potassium intake. Our data demonstrated that there was a decrease in urinary prostasin concentration from baseline to stress, and from stress to recovery. In particular, from baseline to stress, urinary prostasin concentration decreased 2-fold, whereas $\mathrm{U}_{\mathrm{Na}} \mathrm{V}$ increased almost 2-fold. Furthermore, prostasin was inversely correlated with $\mathrm{U}_{\mathrm{Na}} \mathrm{V}$ during stress, that is, lower prostasin was associated with higher $\mathrm{U}_{\mathrm{Na}} \mathrm{V}$. These findings suggest that prostasin could be involved in renal sodium reabsorption, and thus the renal-body fluid control of arterial pressure.

Discovered more than a decade ago, prostasin is one of the only two known mammalian serine proteases that are attached to the plasma membrane via a GPI anchor $(10,33,34)$. It has been predominantly studied in the pathologic development of tumors and cancer such as prostate, breast, and ovarian cancer $(10,31,35)$. Prostasin has recently attracted substantial attention as a potential mechanism underlying sodium and volume homeostasis and subsequent BP regulation, although the production, secretion, and clearance of distal tubular prostasin and urinary prostasin are largely unknown. It is believed that prostasin has channel-activating properties via the proteolytic cleavage of $\gamma \mathrm{ENaC}$ (16-18). Indeed, at the posttranslational level, proteolytic processing is thought to be important if not essential to $\mathrm{ENaC}$ activation.

Conversely, aldosterone regulates sodium balance, extracellular fluid volume, and BP $(2,36,37)$. Aldosterone increases the rate of tubular sodium reabsorption across epithelia at the distal nephron by enhancing ENaC activity. Previously, Narikiyo et al. showed that urinary prostasin secretion was substantially increased in three patients with primary aldosteronism, and that adrenalectomy significantly reduced urinary prostasin secretion (19). In an independent study, Olivieri et al. demonstrated that spironolactone $(100 \mathrm{mg})$, the traditional aldosterone receptor inhibitor, decreased urinary prostasin in five normotensive white adults in whom the renin/aldosterone axis was activated by low sodium intake (defined by urinary sodium $<150 \mathrm{mmol} / \mathrm{d}$ in 24 -h urine), but it was ineffective in five subjects with high sodium intake (defined by urinary sodium $>150 \mathrm{mmol} / \mathrm{d}$ in $24-\mathrm{h}$ urine) (38). Of note, urinary prostasin was evaluated by SDS-PAGE 2D gels, and Western blotting, which are generally considered to be less accurate and robust at the population level compared with the ELISA technique used in this study. We placed our subjects on a sodium- and potassium-controlled diet, yet failed to identify a significant correlation between aldosterone and prostasin at baseline, during stress, or recovery. Wang et al. evaluated the effects of adenovirus-mediated gene transfer of human prostasin on BP regulation and sodium reabsorption in Wistar rats. Elevated plasma aldosterone levels were detected $3 \mathrm{~d}$ after gene transfer and before the development of hypertension, indicating that stimulation of mineralocorticoid production was a primary target of prostasin (20). Alternatively, prostasin might modulate the pressure natriuresis relation, independent of aldosterone.

This study has some limitations. First, plasma and urine samples were collected and assayed only hourly throughout the SIPN protocol. Sample collections at more time points may enable us to better reveal the dynamic relationship between prostasin and $\mathrm{U}_{\mathrm{Na}} \mathrm{V}$. Second, the basal levels of urinary prostasin in our subjects were not examined because we did not collect urine samples before the start of the sodiumcontrolled diet. Decreased dietary sodium intake might exaggerate the role of prostasin via the activation of aldosterone. Conversely, in our SIPN model, aldosterone was suppressed in response to stress, which might mask the true relationship between aldosterone and prostasin under stress. The dynamic 
relationship among urinary prostasin, salt intake, and aldosterone in normotensive adolescents needs to be studied using a salt sensitivity test, e.g. low salt diet $(50 \mathrm{mmol} / \mathrm{d})$ for $5 \mathrm{~d}$ followed by high salt $(150 \mathrm{mmol} / \mathrm{d})$ supplementation for $10 \mathrm{~d}$ $(39,40)$. Third, as discussed above, because plasma aldosterone was only measured hourly, we cannot exclude the role of aldosterone in the pressure natriuresis relation over time in the SIPN model, even though no significant correlations between aldosterone and $\mathrm{U}_{\mathrm{Na}} \mathrm{V}$ were found across baseline, stress, and recovery.

Nonetheless, there have been only few studies investigating the role of prostasin in sodium balance in humans, although prostasin expressed in the distal nephron has been suggested to be an ENaC regulatory mechanism in vitro and in animals since the late 1990s. Our data are the first to indicate that prostasin is likely involved in pressure natriuresis at the population level, specifically in black adolescents. Clinically, considering that urine is easily collected and represents a medium with a relatively low number of interfering proteins, urinary prostasin may be used as a possible biomarker for renal pressure and natriuresis. Our data in black adolescents warrant replication in other populations including white adolescents, normotensive adults, and patients with essential hypertension. Finally, although the cross-sectional correlation between prostasin and stress-induced $\mathrm{U}_{\mathrm{Na}} \mathrm{V}$ was recognized, a longitudinal study with repeated measures over time is under way to elucidate the contribution of prostasin to pressure natriuresis and BP further in youth.

\section{REFERENCES}

1. Guyton AC, Coleman TG 1969 Quantitative analysis of the pathophysiology of hypertension. Circ Res 24:1-19

2. Garty H, Palmer LG 1997 Epithelial sodium channels: function, structure, and regulation. Physiol Rev 77:359-396

3. Gormley K, Dong Y, Sagnella GA 2003 Regulation of the epithelial sodium channel by accessory proteins. Biochem J 371:1-14

4. Pratt JH 2005 Central role for ENaC in development of hypertension. J Am Soc Nephrol 16:3154-3159

5. Vallet V, Chraibi A, Gaeggeler HP, Horisberger JD, Rossier BC 1997 An epithelial serine protease activates the amiloride-sensitive sodium channel. Nature 389:607610

6. Vallet V, Horisberger JD, Rossier BC 1998 Epithelial sodium channel regulatory proteins identified by functional expression cloning. Kidney Int Suppl 67:S109S114

7. Chraibi A, Vallet V, Firsov D, Hess SK, Horisberger JD 1998 Protease modulation of the activity of the epithelial sodium channel expressed in Xenopus oocytes. J Gen Physiol 111:127-138

8. Vuagniaux G, Vallet V, Jaeger NF, Pfister C, Bens M, Farman N, Courtois-Coutry N, Vandewalle A, Rossier BC, Hummler E 2000 Activation of the amiloridesensitive epithelial sodium channel by the serine protease mCAP1 expressed in a mouse cortical collecting duct cell line. J Am Soc Nephrol 11:828-834

9. Adachi M, Kitamura K, Miyoshi T, Narikiyo T, Iwashita K, Shiraishi N, Nonoguchi H, Tomita K 2001 Activation of epithelial sodium channels by prostasin in Xenopus oocytes. J Am Soc Nephrol 12:1114-1121

10. Chen LM, Skinner ML, Kauffman SW, Chao J, Chao L, Thaler CD, Chai KX 2001 Prostasin is a glycosylphosphatidylinositol-anchored active serine protease. J Biol Chem 276:21434-21442

11. Vallet V, Pfister C, Loffing J, Rossier BC 2002 Cell-surface expression of the channel activating protease xCAP-1 is required for activation of $\mathrm{ENaC}$ in the Xenopus oocyte. J Am Soc Nephrol 13:588-594
12. Vuagniaux G, Vallet V, Jaeger NF, Hummler E, Rossier BC 2002 Synergistic activation of $\mathrm{ENaC}$ by three membrane-bound channel-activating serine proteases (mCAP1, mCAP2, and mCAP3) and serum- and glucocorticoid-regulated kinase (Sgk1) in Xenopus oocytes. J Gen Physiol 120:191-201

13. Hughey RP, Mueller GM, Bruns JB, Kinlough CL, Poland PA, Harkleroad KL, Carattino MD, Kleyman TR 2003 Maturation of the epithelial Na+ channel involves proteolytic processing of the alpha- and gamma-subunits. J Biol Chem 278:3707337082

14. Rossier BC 2004 The epithelial sodium channel: activation by membrane-bound serine proteases. Proc Am Thorac Soc 1:4-9

15. Kleyman TR, Myerburg MM, Hughey RP 2006 Regulation of ENaCs by proteases: an increasingly complex story. Kidney Int 70:1391-1392

16. Hughey RP, Carattino MD, Kleyman TR 2007 Role of proteolysis in the activation of epithelial sodium channels. Curr Opin Nephrol Hypertens 16:444-450

17. Carattino MD, Sheng S, Bruns JB, Pilewski JM, Hughey RP, Kleyman TR 2006 The epithelial $\mathrm{Na}+$ channel is inhibited by a peptide derived from proteolytic processing of its alpha subunit. J Biol Chem 281:18901-18907

18. Bruns JB, Carattino MD, Sheng S, Maarouf AB, Weisz OA, Pilewski JM, Hughey RP, Kleyman TR 2007 Epithelial $\mathrm{Na}+$ channels are fully activated by furin- and prostasin-dependent release of an inhibitory peptide from the gamma-subunit. J Biol Chem 282:6153-6160

19. Narikiyo T, Kitamura K, Adachi M, Miyoshi T, Iwashita K, Shiraishi N, Nonoguchi H, Chen LM, Chai KX, Chao J, Tomita K 2002 Regulation of prostasin by aldosterone in the kidney. J Clin Invest 109:401-408

20. Wang C, Chao J, Chao L 2003 Adenovirus-mediated human prostasin gene delivery is linked to increased aldosterone production and hypertension in rats. Am J Physiol Regul Integr Comp Physiol 284:R1031-R1036

21. Iwashita K, Kitamura K, Narikiyo T, Adachi M, Shiraishi N, Miyoshi T, Nagano J, Tuyen DG, Nonoguchi H, Tomita K 2003 Inhibition of prostasin secretion by serine protease inhibitors in the kidney. J Am Soc Nephrol 14:11-16

22. Harshfield GA, Treiber FA, Davis H, Kapuku GK 2002 Impaired stress-induced pressure natriuresis is related to left ventricle structure in blacks. Hypertension 39:844-847

23. Harshfield GA, Wilson ME, Hanevold C, Kapuku GK, Mackey L, Gillis D, Treiber FA 2002 Impaired stress-induced pressure natriuresis increases cardiovascularload in African American youths. Am J Hypertens 15:903-906

24. Barbeau P, Litaker MS, Harshfield GA 2003 Impaired pressure natriuresis in obese youths. Obes Res 11:745-751

25. Wilson ME, Harshfield GA, Ortiz L, Hanevold C, Kapuka G, Mackey L, Gillis D, Edmonds L, Evans C 2004 Relationship of body composition to stress-induced pressure natriuresis in youth. Am J Hypertens 17:1023-1028

26. Harshfield GA, Wilson ME, McLeod K, Hanevold C, Kapuku GK, Mackey L, Gillis $\mathrm{D}$, Edmonds L 2003 Adiposity is related to gender differences in impaired stressinduced pressure natriuresis. Hypertension 42:1082-1086

27. Hanevold CD, Pollock JS, Harshfield GA 2008 Racial differences in microalbumin excretion in healthly adolescents. Hypertension 51:334-338

28. Weinberger MH 1993 Racial differences in renal sodium excretion: relationship to hypertension. Am J Kidney Dis 21:41-45

29. Falkner B 1990 Differences in blacks and whites with essential hypertension: biochemistry and endocrine. State of the art lecture. Hypertension 15:681-686

30. Zhu H, Yan W, Ge D, Treiber FA, Harshfield GA, Kapuku G, Snieder H, Dong Y 2008 Relationships of cardiovascular phenotypes with healthy weight, at risk of overweight, and overweight in US youths. Pediatrics 121:115-122

31. Mok SC, Chao J, Skates S, Wong K, Yiu GK, Muto MG, Berkowitz RS, Cramer DW 2001 Prostasin, a potential serum marker for ovarian cancer: identification through microarray technology. J Natl Cancer Inst 93:1458-1464

32. Hall JE 2003 The kidney, hypertension, and obesity. Hypertension 41:625-633

33. Yu JX, Chao L, Chao J 1994 Prostasin is a novel human serine proteinase from seminal fluid. Purification, tissue distribution, and localization in prostate gland. J Biol Chem 269:18843-18848

34. Yu JX, Chao L, Chao J 1995 Molecular cloning, tissue-specific expression, and cellular localization of human prostasin mRNA. J Biol Chem 270:13483-13489

35. Chen LM, Chai KX 2002 Prostasin serine protease inhibits breast cancer invasiveness and is transcriptionally regulated by promoter DNA methylation. Int J Cancer 97:323-329

36. Funder JW 1993 Aldosterone action. Annu Rev Physiol 55:115-130

37. Connell JM, Davies E 2005 The new biology of aldosterone. J Endocrinol 186:1-20

38. Olivieri O, Castagna A, Guarini P, Chiecchi L, Sabaini G, Pizzolo F, Corrocher R, Righetti PG 2005 Urinary prostasin: a candidate marker of epithelial sodium channel activation in humans. Hypertension 46:683-688

39. Wilson DK, Sica DA, Miller SB 1999 Effects of potassium on blood pressure in salt-sensitive and salt-resistant black adolescents. Hypertension 34:181-186

40. Wilson DK, Bayer L, Sica DA 1996 Variability in salt sensitivity classifications in black male versus female adolescents. Hypertension 28:250-255 